\title{
Tarihsel Süreç İçerisinde Fransız Temyiz Mahkemesinin Gelişimi ${ }^{*}$
}

\author{
The Evolution of The French Court of Cassation in The Historical \\ Process
}

\section{Kâmil Yıldırım* (D), Ozan Tok ${ }^{* * *}$ (D)}

\section{öz}

Fransız hukukunda modern anlamda Temyiz Mahkemesi, ihtilalden sonra hukukun kurumsallaşması ve yeknesaklaştırılmasına duyulan ihtiyaç sonucu ortaya çıkmıştır. Modern dönemle birlikte daha önce dağınık bir yapıya sahip olan Fransız Adli Teşkilatı kurumsallaştırılmış ve kanunların yeknesak biçimde uygulanmasının gözetilmesini sağlamak için de Tribunal de cassation kurulmuştur. Eski rejimde (ancien régime) ise Fransız hukukunda modern anlamda temyize benzeyen tek kurum Kral'ın Konseyi (Conseil du roi) olmuştur. Conseil du roi, kralın emirnamelerinin parlemanlar (parlemants provinciaux) tarafından uygulanıp uygulanmadığını denetlemekteyken Tribunal de cassation, derece hâkiminin kararının yasa koyucu tarafından çıkarılan kanunlara uygun olup olmadığını denetlemektedir. Yasama yorumunun (référé législatif) kaldırılmasından sonra ise Cour de cassation gerçek bir yargılama merci hüviyetini kazanmıştır.

Anahtar Kelimeler: Derece hâkimi, Conseil du roi, Conseil des parties, Parlemanlar, Tribunal de cassation, Cour de cassation.

\section{ABSTRACT}

A court of cassation was founded in French law to fulfill the need for the institutionalization and unification of law. In the modern era, the French judicial organization, which subsequently had a primitive character, was institutionalised and to serve this mission the Court of Cassation was founded. For the era of the Ancien Régime, the only institution which fulfil the modern court of cassation was the King's Council (Conseil du roi). The object of the king's council was to control obedience to ordinances by the provincial parliaments (parlemants provinciaux) while the modern court of cassation was established to control a single application of the laws by the judges of first and second instances. After the abolition of the référé législatif, the Court of Cassation was able to become a real judicial institution.

Keywords: Judge of first and second instances, Conseil du roi, Conseil des parties, Tribunal de cassation, Cour de cassation.

* $\quad$ Bu makale, Marmara Üniversitesi Lisansüstü Eğitim ve Öğretim Yönetmeliği’nin (5.10.2017 tarihli ve 30201 Sayılı Resmî Gazete) 27. maddesinin 2. fikrasınca öngörülen doktora tezinin savunabilmesi için tezden makale üretilmesi lüzumu uyarınca "Fransız ve Türk Medeni Yargılama Hukuklarında Temyiz Mahkemesinin Yapısı ve İşlevi” isimli tezden üretilmiștir.

** Prof. Dr., Marmara Üniversitesi Hukuk Fakültesi Medeni Usul ve İcra İflâs Hukuku Anabilim Dalı, ORCID: 0000-0002-14275529.

*** Ar.Gör., Sakarya Üniversitesi Hukuk Fakültesi Medeni Usul ve İcra İflâs Hukuku Anabilim Dall, Marmara Üniversitesi Sosyal Bilimler Enstitüsü Doktora Öğrencisi, E mail: ozantok@sakarya.edu.tr, ORCID: 0000-0003-1372-9397.

Sorumlu Yazar/Correspondence Author: M. Kâmil Yıldırım

E-posta/E-mail: kamilyildirim@marmara.edu.tr 


\section{Giriş}

Modern anlamda temyiz mahkemeleri birçok süreçten geçerek bugünkü teknik hâlini alabilmiştir. Modernleşme sürecine dâhil olan bütün ülkeler, hukuk uygulamasını yeknesaklaştırmaya ve bireylere adil yargılama hakkı temelinde başvuru imkânı sağlayan ve tecrübeli hâkimlerden oluşan bir kanun yolunu tesis etmeye gayret etmişlerdir. Kamusal ve bireysel menfaati birlikte temin eden bu kanun yolu şüphesiz temyizdir. Fransız hukukunda temyiz kanun yolu Fransız İhtilali'nden sonra öncelikle düzenlenen bir hukuki çare olmuştur. Temyiz kanun yolunun kaderi, ihtilalden sonra tesis edilen Fransız Temyiz Mahkemesi Tribunal de cassation ile tayin edilmiştir.

Tribunal de cassation’un tesisine kadar Fransız hukukunda temyiz benzeri hiçbir kurum bulunmadığını ifade etmek doğru değildir. Nitekim eski rejimde (ancien régime) birçok derece mahkemesinden oluşan dağınık ve birçok gruba imtiyaz tanıyan bir adli teşkilat yapısı bulunmaktadır. Bununla birlikte gerek Orta çağ gerekse de modern öncesi dönemde Fransız hukukunda belirli bir kanun yolu rejimi kabul edilmektedir. Bu kanun yolu mahkemeleri, birçok eski hukuk sisteminde olduğu gibi, bazı uyuşmazlıkları ikinci veya üçüncü derece mahkemesi olarak görmekteyken değeri yüksek bazı hukuki uyuşmazlıkları ise ilk derece mahkemesi olarak incelemektedir. Çalışmada bu kanun yolu mahkemelerinin temyiz niteliğine haiz olup olmadığı ayrıca incelenecektir.

Fransız hukukunda temyiz benzeri ilk kurumsa, yerel parlemanların kralın emirnamelerini uygulamakta tereddütler yaşamaları sebebiyle gücü artan Kral'ın Konseyi (Conseil du roi) olmuştur. Kral'ın Konseyi (Conseil du Roi), esasen monarkın yürütme ve danışmanı organıdır. Ancak Konsey kendi içerisinde kurullara ayrılarak içerisinden temyiz mahkemesi benzeri bir yapı olan Conseil des parties alt kurulunu çıkarmıștır. Conseil des parties kurlunun asıl görevi ise bireye ayrı bir hukuki çare olanağı sağlamaktan çok kralın emirnamelerinin uygulanmasını sağlamaktır.

Fransız İhtilali ile Kral’ın Konseyi (Conseil du roi) ortadan kaldırılmıştır. Ancak Konsey’in içerisindeki temyiz mahkemesi benzeri yapıya sahip olan Conseil des parties yerine Tribunal de cassation kurulmuştur. Temyiz Mahkemesi’nin (Tribunal de cassation) yapısı ve günümüze kadar geçirdiği dönüşüm çalışmanın önemli konularından birini teşkil etmektedir. Çalışmada ayrıca modern Fransız Temyiz Mahkemesi’nin (Cour de cassation) Fransız hukuku içerisinde belirli bir hukuk kültürünün devamını sağladığı vurgulanmaya çalışılacaktır.

\section{MODERN ÖNCESI DÖNEMDE (ANCIEN REGIME) YARGI TEŞKILATI VE KANUN YOLLARI}

\section{A. ESKi REJIM'DE (ANCIEN RÉGIME) YARGILAMA HUKUKUNA ILIŞKIN ESASLAR}

Eski rejim (ancien régime), Fransız Hukuku’nun 1789 ihtilaline kadar süren dönemini konu almaktadır. Fransız ihtilali, aydınlanma ideolojisinin de yardımıyla siyasi ve hukuki kurumların köklü bir şekilde modernleşmesine sebebiyet vermiş; üst yapıdaki bu modernleşme süreci şüphesiz 
adli teşkilatı doğrudan etkilemiştir ${ }^{1}$. Ancak ihtilal öncesi, kimi zaman dini bilgilerle birleşmiş karma bir hukuk bilgisi geçerli olmuştur² ${ }^{2}$ Orta çağ hâkimi her şeyden önce Hristiyanlığın çizdiği bir bilince sahip olup hukuki mülahazalarının temelini dini bilgi oluşturur ${ }^{3}$. Orta çă̆ Avrupası ve Fransa’sında yarg1 ve bürokrasinin etkili yerlerinde görev alabilmek için memurun dini bilgisinin iyi olması gerekmektedir.

Modern öncesi Fransảda neredeyse beş dereceden oluşan oldukça dağınık bir yargı teşkilatı bulunmaktadır ${ }^{4}$. Bununla birlikte 16. yüzyıldan sonra Fransảnın siyasi olarak merkezileşerek monarkın yönetimde etkisini artırması, modern öncesi dönemde hukuk sisteminin dağınık karakterinin zayıflamasına ve hukukun yekpareleşmesine vesile olmuştur ${ }^{5}$. Eski rejim döneminde Fransảnın siyasi rejimi de mutlak monarşidir. Ancak iktidarın temeli tanrı olarak görüldüğü için monark (kral) da tanrının dünyadaki vekili olarak kabul edilmektedir. Bu sebeple yargılama yetkisi de krala ait olup bu yetki emirnameler aracıllğıyla çeşitli kurumlara delege edilmektedir ${ }^{6}$. Diğer taraftan hukuk kuralları da seküler ve dini kurallar olmak üzere ikiye ayrılmaktadır ${ }^{7}$. Ancak bilhassa Orta çağ Fransảsında dini kuralla dini olmayan kuralların iç içe geçtiğinden iki farklı karakterdeki hukuk kurallarına ilişkin açık bir ayrım yapılamamaktadır ${ }^{8}$.

Orta çağa ait bu siyasi tahayyül, Martin Luther'in Protestanlı öğretisinin Fransa'da da kabul görmesiyle önemli bir engelle karşılaşır. Zira, "insanlardan ziyade; tanriya itaat etmek gerekir" şeklindeki Protestan önerme orta çağ Avrupa iktidarlarını tedirgin etmeye başlamıştır. Bu önermeyi takiben gerçekleşen birçok Protestan isyanı ise Fransa'da kaosa yol açtığından toplumda monarkın otoritesine karşı teveccüh baş göstermiştir9 .

Gerek devlet kurumlarının gerekse de halkın uyacağı kurallar bütünü, çoğunlukla Fransa’da teamül kaynaklıyd ${ }^{10}$. Başka bir deyişle, yazılı veya bir ölçüde kurumsal kurallardan bahsetmek mümkün

1 Halpérin J.L., 'Le droit privé de la Révolution: héritage législatif et héritage idéologique'(2002) (2) Annales historiques de la Révolution 135.

2 Nitekim 16. yüzyılda hâkimin takdir yetkisini kullanmasında etkili olan "vicdan" kurumunun hem de akıla müracaatı zorunlu kıldığı böylelikle yargılamanın da melez bir karakter taşıdığı ifade edilmektedir (Renoux-Zagamé, M.F., 'Répondre de l’obéissance. La conscience du juge dans la doctrine judiciaire à l'aube des Temps modernes' iç La conscience du juge dans la tradition juridique européenne (PUF 1999) 162).

3 Carbasse, J.M., 'Le juge entre la loi et la justice: approches médiévales, La conscience du juge dans la doctrine judiciaire à l'aube des Temps modernes' iç La conscience du juge dans la tradition juridique européenne (PUF 1999) 68.

4 Piant H., Une Justice Ordinaire, Justice Civile et Criminelle Dans La Prévoté Royale de Vaucouleurs Sous L’Ancien Régime (Pesses universitaires de Rennes 2006) $22 \mathrm{vd}$.

5 İngiltere’nin aksine Fransa'da devlet teşkilatı merkezi olmaktan uzaktır. Bunda feodal beylerin kral karşısındaki gücü etkili olmuştur. Feodal lortlar, kralın karşısındaki gayri resmi güç odaklarıdır. Fransa devlet teşkilatının bu yapısı "anarşistfeodalizm” olarak adlandırılmaktadır (Van Caenegem R.C., History of European Civil Procedure, Civil Procedure, Chapter 2, (Volume XVI New York 1973) 32).

6 Teomete-Yalabık F., 'Fransız Hukukunda Temyizin Tarihi Gelişimi ve Temyiz Sebepleri' (İstanbul Üniversitesi Sosyal Bilimler Enstitüsü 2010) 32.

7 Saint-Bonnet F. ve Sassier Y., Histoire des Institutions Avant1789 (6e édition, LGDJ 2019) 281, 282.

8 Forcadet P.A., 'Les premiers juges de la Cour du roi au XIII e siècle' (1922) (94)2 Revue historique de droit français et étranger 197.

9 Saint-Bonnet/Sassier 284.

10 Forcadet 203. 
değildi ${ }^{11}$. Ancak özellikle ülkenin kuzeyinde 16. yüzyıldan itibaren teamüllerin kodifikasyonu başlar. Böylelikle dağınık hukuki rejim daha teknik bir yapıya bürünmeye yönelir ${ }^{12} .1560$ tarihli Orléans Emirnamesi ve kraliyetin mallarının rejimini düzenleyen 1566 tarihli Édit de Moulins, teamüllerin kodifikasyonu faaliyetiyle ortaya çıkmıştır.

Eski rejim döneminde kuvvetler ayrıllğı söz konusu olmadığ 1 için yargı yetkisini haiz birçok kurumun tam anlamıyla birer mahkeme olduğundan da bahsetmek mümkün değildir. Esasen modern öncesi birçok coğrafyada yargı kurumları aynı zamanda idari görev ve yetkilere sahip olmaktadır. Modern öncesi Fransız yargı teşkilatı da adli ve idari görevleri birlikte yürütmektedir.

Eski rejimdeki yargı teşkilatı, Fransa’nın siyasi karakterine benzer şekilde oldukça dağınık bir yapıya sahiptir. Eski rejimin karakteristik özellikleri, kuvvetler birliği (la confusion du puvoir), imtiyaz rejimi (le régime du privilège), mutlakıyet (labsolutisme), idari monarşi (la monarchie administrative), merkeziyetçiliğe doğru gelişim (le développement de la centralisation), devletin doğuşu (la croissance de l' État) olarak tarif edilmektedir ${ }^{13}$.

Yargı yetkisi monarka (krala) aittir. Ancak böylesine büyük bir coğrafyada bütün yargılamalarının kral tarafından yapılması mümkün olmadığı için, kral adına mahkeme benzeri kurumlar vekaleten (justice déléguée) ${ }^{14}$ karar vermektedir ${ }^{15}$. Yukarıda belirtildiği gibi bütün Fransa coğrafyası kralın yargı yetkisine girmemektedir. Senyör ve kilise yargılamaları, krallı̆̆ın yargılama tekelini önemli bir istisna teşkil etmektedir ${ }^{16}$. Bununla birlikte kral, senyörlerin senyörü (le chef seigneur) olarak kabul edildiği için senyör yargılamaları da bir ölçüde hukuki temele sahiptir. Senyör yargılamaları ve krallık yargılamaları arasındaki ilişki "krallığa ilişkin vakıanın (cas royal)" varlığına göre değişmektedir. Bir vakıanın etki alanın genişliği veya sonucunun kamu düzeni üzerindeki etkisi, olayın veya fiilin krallığa ilişkin vakıa olarak değerlendirilmesine sebep olur ${ }^{17}$. Bunun dışında senyör yargılamaları ve hatta kilise yargılamaları sonucunda verilen kararlara karşı krallık mahkemelerinde istinaf yoluna başvurulması mümkündür. Böylece krallık yargılaması dışında verilen kararların, krallık mahkemeleri tarafından kontrolü sağlanmaktadır. Yargı sisteminin normatif anlamda yeknesaklaştırılması ise ancak modern dönemde mümkün olabilmiştir ${ }^{18}$.

11 Carbasse 67.

12 Barbiche B., Les institutions de la monarchie française à lépoque moderne XVIe-XVIIIe siècle, (PUF 2012 ) 60.

13 Barbiche, Institutions 3.

14 Esasen vekaleten adalet (justice déléguée), iki farklı hâli içermektedir. Modern öncesi dönemde monark, tanrının yeryüzündeki vekili olarak kabul edildiğinden kural olarak Fransa coğrafyasında en üst yargı merci olan monark, vekalet aldığı tanrı adına karar vermektedir. Bu husus vekaleten adaletin birinci anlamını açıklar. Diğer taraftan yargı teşkilatında bir kurumsallaşma söz konusu olmadığı için modern öncesi Fransa'daki mahkemeler de kamu adına değil; monark adına karar vermektedir. Kral adına karar veren yargı mercileri, yargılama yetkisini kralın kendilerine bu konuda vermiş olduğu vekaletten almaktadır. Bu husus da vekaleten adaletin ikinci yönüne karşılık gelmektedir. Bu konuda bkz. Carbasse 69 vd.

15 Barbiche, İnstitutions 47.

16 Barbiche, İnstitutions 48.

17 Barbiche, İnstitutions 50.

18 Petit J.G., 'La Justice en France, 1789-1939. Une étatisation modèle?' (2002) (1)6 Crime, Histoire \& Sociétés 86. 


\section{B. DERECE MAHKEMELERI}

Fransız yargı teşkilatının ilk derece mahkemesi hemen hemen her bölgede bulunan prévôté mahkemeleridir ${ }^{19}$. Bu ilk derece mahkemeleri (prévôté) ceza ve hukuk yargılaması bakımından görevli oldukları gibi ayrıca kral adına vergi toplama gibi idari yetkilere de sahiptir ${ }^{20}$. İlk derece mahkemelerinin (prévôté) topladıkları vergileri saklama ve belli ilkeler çerçevesinde paylaştırma yetkisini de haiz oldukları belirtilmektedir ${ }^{21}$. İlk derece mahkemesinin yetkisini düzenleyen L'Edit de Crémieux'nün 20. maddesine göre: "Medeni hukukun, kişiler hukukunun, eşya hukukuyla haksız ve fiil rejimi ve ceza hukuku bakımından prévôté birinci derece yargılamasını yürütmekte olup istinaf mahkemesi sıfatıyla ikinci derece yargılaması baillis ve sénéchaux tarafından yerine getirilir." Buna göre prévôté aksine düzenleme olmadıkça hukuk ve ceza yargılamasında genel görevli mahkeme sıfatını haizdir ${ }^{22}$. Ayrıca prévôté yargılamalarının laik hukukla ilgili olduğunu da belirtmek gerekmektedir ${ }^{23}$.

Krallık toprağındaki her prévôté mahkemesinin kendisi teşkilatı bulunmaktadır. Teşkilatın içerisinde hâkimlere (prévôts) idari ve adli görevlerine yardımc1 memurlar (assesseurs) bulunur ${ }^{24}$. Prévôt, yargılama sırasında yanında bulunan memurların görüşünü alabileceği gibi kendisinin katılmadığ yargılamalarda yerine birinci sorumlu memuru (lieutenant) yargılamayı yürütebilmektedir ${ }^{25}$.

Louis VII döneminden itibaren ilk derece hâkimlerinin (prévôts) görevlerini kötüye kullanmalarının engellenmesi için görev süreleri üç yıl olarak belirlenmiştir ${ }^{26}$. Hâkimlerin (prévôts) idari ve yargısal görevlerini yerine getirebilmeleri amacıyla krallar emirnamelerle önlem alma gereğini duymuşlardır. Örneğin hâkimler (prévôts) avukat veya kamu görevlisi olamazlar. Din görevlilerinin sahip oldukları etki sebebiyle prévôt olarak atanması kabul edilmemiştir ${ }^{27}$.

İlk derece mahkemesinin (prévôté) yargı çevresi mutlak surette kralın doğrudan senyörü olduğu topraklar olarak belirlenmiştir ${ }^{28}$. Yargı çevresine ilişkin bu ayrımın temelinde Fransa’nın toprak mülkiyetine dayalı siyasi yapısı rol oynamaktadır. Kral, eski rejim döneminde senyörlerin senyörü (chef seigneur) olarak nitelendirilmekle birlikte bütün topraklara sahip değildir. Diğer senyörlere ait topraklarda meydana gelen uyuşmazlıklar bakımından prévôté ilk derece mahkemesi olarak görevli değildir ${ }^{29}$. Bununla birlikte kural olarak ilk derece yargılaması yapan prévôté, senyör yargılamalarının

19 Van Caenegem 33.

20 Verpeaux N., 'Maires, Prévôts, Doyens, Les İntermédiaires Entre Seigneurs et Exploitants' (2011) (36) 2 Histoire \& Sociétés Rurales 13; Piant 23; Barbiche, İnstitutions 347; Chénon, Histoire, Tome I 848.

21 Verpeaux 29.

22 Piant 24.

23 Verpeaux 13-14.

24 Gravier H., 'Essai sur les Pprévots royaux du XI e au XIV e siècle' (1903) (27) 5 Nouvelle revue historique de droit français et étranger 649.

25 Gravier 650.

26 Saint-Bonnet/Sassier 183.

27 Gravier 651.

28 Piant 23.

29 Duquesne Q., 'Du juge seigneurial au juge de paix. Les détenteurs des fonctions judiciaires de proximité de la fin de l’Ancien Régime au Consulat: le cas de l'Isère' (2010) (29) 2 Histoire, économie \& société 46. 
kararlarını istinaf mahkemesi olarak inceleme yetkisine sahiptir ${ }^{30}$. Aynı uyuşmazlık bakımından birbirinden farklı mahkemelerde dava açmak mümkün olduğu gibi, herhangi bir kesin yetki kuralı söz konusu olmadığı için birbiriyle ilişkisi olmayan ilk derece mahkemelerinde dava açmak mümkündür ${ }^{31}$.

Mahkemenin görevinin tespitinde, yargı çevresi içerisinde hem ilk derece hem de istinaf mahkemesi karakterini haiz baillages olarak adlandırılan ikinci derece mahkemesinin bulunup bulunmaması önem arz eder. Kural olarak ilk derece mahkemesi prévôté özel hukuktan kaynaklanan uyuşmazlıklar ve kabahat teşkil eden ceza hukuku uyuşmazlıkları bakımından görevlidir ${ }^{32}$.

Hiyerarşik olarak, ilk derece mahkemesinin üzerinde sénéchaussées veya baillage olarak adlandırılan ikinci derece mahkemeleri yer almaktadır. Baillage yargılama faaliyetinin dışında askeri, idari ve iktisadi yetkilere sahip olsa da tıpkı prévôté gibi zamanla bu yetkilerini uzman idari kurumlara devretmek zorunda kalmıştır ${ }^{33}$. Ancak bu yetkileri kaybedene kadar, prévôté bilhassa vergiyle alakalı işlemler üzerinde denetim yetkisine sahip olmuştur. Yargı teşkilatında baillage ve prévôté arasındaki derece ilişkisinin yanında idare hukuku anlamında bir hiyerarşik ilişki bulunduğu anlaşılmaktadır ${ }^{34}$. Bu mahkemeler, kural olarak istinaf mahkemesi karakterini taşıyan ikinci derece mahkemeleridir ${ }^{35}$. Buna göre prévôté kararlarına karşı baillage olarak adlandırılan ikinci derece mahkemelerine istinaf müracaatında bulunmak mümkündür. Ancak istisnai olarak baillage bazı asillerin ve kamu görevlilerinin tarafı olduğu uyuşmazlıkları ilk derece mahkemesi olarak görebilmektedir ${ }^{36}$. Bunun dışında senyör yargılamalarının ceza hukukuna ilişkin kararlarını da ikinci derece mahkemesi olarak inceleyebilirler.

Prévôté ve baillage arasındaki denge, 14. yüzyıldan sonra bozulmaya başlamaktadır. Zira baillage için öngörülen kazai ve idari yetkileri prévôté aleyhine genişlemiştir. Bu da baillage tarafından ilk derece mahkemesi sıfatıyla görülen uyuşmazlık sayısının artmasına yol açmıştır ${ }^{37}$.

Kural olarak bir kanun yolu merci olan üçüncü derece mahkemesi présidiaux 1552 yllında bir emirname ile kurulmuştur. Présidiaux, baillages kararlarına müracaat edilebilen bir üçüncü derece mahkemesidir ${ }^{38}$. Présidiaux bir görüşe göre yeni mevkiler yaratarak krallı̆̆ın gelirinin yükselmesi amacıyla tesis edilmiştir ${ }^{39}$. Özel hukuktan kaynaklanan ve 1552 tarihi itibariyle 250 kuruşun (livres) altında olan uyuşmazlıklar bakımından présidiaux temyiz benzeri bir yargılama yürütmektedir ${ }^{40}$.

30 Saint-Bonnet/Sassier 422.

31 Piant $22 \mathrm{vd}$.

32 Gravier 651.

33 Barbiche, İnstitutions 348.

34 Gravier 659.

35 Rouland N., Introduction historique au droit (PUF 1998) 389.

36 Barbiche, Institutions 349.

37 Chénon E., Histoire générale du droit français public et privé des Origines à 1815, 1er Tome (Receuil Sirey 1926866.

38 Saint-Bonnet/Sassier 422; Barbiche, İnstitutions 349.

39 Claerr R., 'Les Présidiaux créations, suppressions, archives et bibliographie' (2011) Annuaire-Bulletin de la Société de L'histoire de France 98.

40 Barbiche, İnstitutions 350; Breen M. P., 'Law, Society, and the State in Early Modern France' (2011) (83) 2 The Journal of 
Diğer taraftan présidiaux, prévôté ve baillage tarafından görülemeyen ceza davalarına ilk derece mahkemesi olarak bakmaktadır ${ }^{41}$. Présidiaux, baillage tarafından ilk derece mahkemesi sıfatıla verilen kararlara karşı da istinaf benzeri bir yargılama yapmaktadır ${ }^{42} .1629$ ve 1642 tarihleri arasındaki kayıtlarda Fransa coğrafyasında yaklaşık otuz üç adet présidaux mahkemesinin bulunduğu anlaşılmaktadır ${ }^{43}$. Krallık yargılamaları (juridiction royalle) olarak adlandırılan prévôté, baillages ve presidiaux 6 Eylül 1789 tarihli Kanunla kaldırılmıştır.

\section{BIR KANUN YOLU MERCI OLARAK BÖLGESEL PARLEMANLAR (LES PARLEMANTS PROVINCIAUX)}

Baillage tarafından değeri 500 kuruştan (livres) fazla olan uyuşmazlıklar verilen kararların yeniden incelenebilmesi için doğrudan parlements'lara müracaat etmek gerekmektedir. Geç sayılabilecek bir tarihte kurulan présidiaux mahkemelerinden önce baillage kararlarına karşı son derece mahkemesi olarak parlemanlara müracaat edilmekteydi. Esasen présidiaux mahkemeleri kuruldukları tarih itibariyle Fransa yargı teşkilatının modernleşme sürecinin bir ürünü olarak kabul edilir. Ancak baillage mahkemelerinden çok daha önce kurulan yerel parlemanlar, (parlements provinciaux) gerçek birer kanun yoludur. Zira parlemanlar, yargı çevreleri içerisinde son derece mahkemesi olarak kabul edilmektedir. Bu noktada parlemanların yargısal yetkilerinin oldukça geniş olduğunu vurgulamak gerekmektedir. Zira parlemanlar, krallık derece mahkemesi hüviyetinde kabul edilmeyen senyör mahkemeleri ve kilise mahkemelerinin kararlarına karşı da müracaat edilebilecek birer kanun yolu mahkemesidir ${ }^{44}$.

Parlemanların birer istinaf mahkemesi mi yoksa temyiz mahkemesi mi olduğu hususu tartı̧̧maya açıktır. Öncelikle belirtmek gerekir ki 18. yüzyılda ülke genelinde yalnızca on üç adet bulunan parlemanlar yalnızca kanun yolu yargılaması olarak görev yapmamakta; bazı uyuşmazlıkları birinci derece mahkemesi olarak görmektedir ${ }^{45}$. Bununla birlikte parlemanların ilk derece mahkemesi sıfatıyla yargılama yapmalarının istisnai bir durum olduğu belirtilmelidir ${ }^{46}$.

Kanun yolu yargılamasının niteliği bakımındansa parlemanların istinafbenzeri bir yargılama yaptığını söylemek daha doğru olacaktır. Zira parlemanlar, önlerine gelen uyuşmazlıkları yeniden tahkikat yaparak incelemektedir. Esasen parlemanların belirli bir yarg1 çevresi olduğu düşünüldüğünde istinaf benzeri yargılamalar yapmasının niteliklerine uygun düştüğü daha iyi anlaşılabilir. Hâlbuki

Modern History 366.

41 Claerr 97-98.

42 Marion M. 'A Propos de la géographie judiciaire de la France sous l’ancien régime. La Question du ressort des présidiaux' (1905) (89) 1 Revue Historique 81.

43 Claerr 99-100.

44 Lemaître A. J., 'Le pouvoir réglementaire Les arrêts sur remontrances du procureur général du roi au parlement de Bretagne' (2015) (122) 3 Annales de Bretagne et des Pays de l'Ouest 151.

45 Barbiche, İnstitutions 345.

46 Van Caenegem 33. 
Conseil du roi, bütün bölgesel parlemanların kararlarını inceleyebilme yetkisine sahip olduğundan temyiz benzeri bir yargılama yürütmektedir.

Parlemanların Fransız İhtilali'ne kadar artırdıkları siyasi otoritesinin temelinde yalnızca yargısal görevleri bulunmaz. Parlemanlar ayrıca yargı çevreleri içeresinde krallık polisiyle birlikte görev yapan bir kolluk gücüne sahiptir ${ }^{47}$.

Çok sık olarak toplanmayan ve toplandığı hâllerde de kralın istekleri doğrultusunda karar alan Etats généraux meclislerinden farklı olarak parlemanların siyasi bir ağırlıkları da bulunmaktadır ${ }^{48}$. Nitekim Fransa tarih doktrininde yeni eğilim, parlemanları kral ve halk arasında bir aracı olarak görmeye yönelmektedir ${ }^{49}$. Öyle ki parlemanlar, kanun tasarıları hakkında bildirdikleri görüşler ve anayasal teamüllere yaptıkları atıflarla eski rejimde yürütme ve yasama karşısında yargının anayasal bir denge işlevini üstlenmesini sağlamışlardırº ${ }^{50}$ Aslında parlemanlar siyasi ağırlıklarını yapmış oldukları yargılamanın işlevselliğine borçludur. Parlemanlar, Fransadaki modern düşüncenin de etkisiyle kendilerini halkı idarenin keyfi işlemlerine karşı koruyan bir yapı olarak görmeye başlamışlardır ${ }^{51}$. İște bu düşünce 18. yüzyıl ortalarında parlemanların krala kanun tasarıları hakkındaki görüşlerini içeren yazıların (remonatraces) bildirilmesini sağlamıştır ${ }^{52}$.

Parlemanlarla kral arasındaki yasa yapımını konu alan gerilim, Fransa yargısında anayasal tartışmalara da sebep olmuştur. Parlemanlara göre kralın yasaların üzerinde, ortada hâlen bir teamül hukuku olduğu için, doğal hukuktan kaynaklanan yasalar bulunmaktadır. Şüphesiz ki yasama faaliyeti krala aittir; ancak kralın yasaları da bu anayasal teamüle uygun olmalıdır ${ }^{53}$. Parlemanlar bilhassa kralın, parleman yargılamalarına ilişkin düzenlemelerini (enregistrements) incelemekte; hatta yeri geldiğinde bu düzenlemelere ilişkin yerindelik denetimi dahi yapmaktayd1 ${ }^{54}$. Storez-Brancourt, 18. yüzyılın ortasından itibaren çeşitli parlemanların kararlarında "monarşinin yasalarının koruyucusu", "hukuk devleti (État de droit)", kanun yapımında "kralın yasal danışmanı (le conseil legal du roi)", "anayasacılık (constitution et lois de la monarchie)", "milletin temsicilsi (représentant de la nation)"

47 Lemaître 153.

48 Coste L. 'Des corps intermédiaires sous l’ancien régime: revendication ou réalité?' (2016) (35) 1 Histoire, Économie Et Société 15 .

49 Coste 15; Breen 361; Swann J., 'Repenser les parlements au xviiie siècle:du concept de l'opposition parlementaire à celui de culture juridique des conflits politiques' iç Alain J Lemaître (edr) Le monde parlementaire au XVIIIe siècle : L'invention d'un discours politique (Presses Universitaires de Rennes 2010) 17.

50 Saint-Bonnet, François, 'Le constitutionnalisme des parlementaires et la justice politique. Les équivoques des lits de justice du XVIIIe siecle”, Quelle culture politique en héritage?' (2011) (15)1 Parlement(s), Revue d'histoire politique 17.

51 Coste 18; Swann 18.

52 Bu konuda detaylı bir çalışma için bkz. Chaline O., 'Cassations et évocations dans les remontrances des parlements Au XVIII e.' (2010) (29) 3 Histoire, économie \& société 58 vd.

53 Barbiche, İnstitutions 355.

54 Rouland 388. 
gibi ifadelere rastlandığını belirtmektedir ${ }^{55}$. Yazara göre bu kavramların kullanılması, dönemin ruhuyla bağlantılıdır ${ }^{56}$.

1788 yılındaki kararlarda artık hâkimlik teminatının da bir anayasal teamül olarak görüldüğü anlaşılmaktadır. Bu retorik, parlemanları basit bir istinaf veya temyiz benzeri mahkemeden, yasama faaliyetine ortak olmayan çalışan politik bir yapıya doğru götürmüştür. Öyle ki parlemanlar, kendileri ile alakalı düzenlemeler hariç (enregistrements) yerindelik denetimi yapmadan, kralın yasalarını doğal hukuk temelli anayasal teamüllere uygunluğunu denetlemek istemişlerdir ${ }^{57}$. Böylece parlemanlar ve krallık arasındaki gerilim, kralın yetkilerini kullanmasına anayasal bir denge rejimi getirmişti $^{58}$. Hatta parlemanların, normatif kural koyma yetkisi monarka ait olmasına rağmen genel düzenleyici işlemler yapmaya teşebbüs ettikleri belirtilmektedir ${ }^{59}$.

Doktrinde genel eğilimi, parlemanların eski rejimin muhafazası konusunda istekli olmaları sebebiyle, kurumların tadilini içeren reform yasalarına karşı istikrarlı bir muhalefet geliştirdiği fikri oluşturmaktadır ${ }^{60}$. Parlemanların kral tarafından hazırlanan vergi kanunları veya yeni vergi teşebbüslerine karşı bildirdiği görüşler (remontraces) vergilerin kamuoyu nazarında da kabulü için önem arz eder ${ }^{61}$. Bütün bunlar parlemanların kamuoyu desteğini almasını sağlamıştır ${ }^{62}$.

1763 yılında 15. Louis’nin (Louis XV) şansölyesi tarafından parlemanların faaliyetleri ile alakalı olarak sarf edilen sözler, krallık ve parlemanlar arasındaki yetki geriliminin anlaşılması bakımından oldukça açıklayıcıdır: "Parlemanlar, kral tarafindan halkın temsilcisi değil; hâkimi olmaları amacıyla tesis edilmiştir. Onlar milletin temsilcisi değil; kralın memurudur ${ }^{63}$." Ancak bütün bu siyasi çekişmeye rağmen parleman ve krallık ilişkisinin bir hukuk politikası (judicial politics) çerçevesinde gerçekleştiğine yönelik görüşler bulunmaktadır. Bu görüşlere göre krallık bürokrasinin içinde, kral tarafından ilan edilen kanunların parlemanların onayıyla daha etkili olacağını düşünen bürokratlar bulunmaktadır ${ }^{64}$.

55 Storez-Brancourt İ. 'C'est légal parce que je le veux: loi et constitution dans le face à face du roi et du Parlement à la fin de l'Ancien Régime, Le Parlement de Paris face aux réformes de Silhouette (1759)' (2011) (15) 1 Parlement(s), Revue d'histoire politique 62 .

$$
\text { Bretag }
$$
Bretagn ki vapıların temizlenmesine ilişkin bir tasarı hazırlamışır. Bununla birlikte kralın yasa koyma gücü karşısında Bretagne Parlemanı’nın normatif kural koyucu işlemlere karşı yine de mesafe aldığı anlaşılmaktadır. Bu konuda bkz. Pichard-Rivalan M., 'Un parlement débutant ? Les hésitations
(2015) (122) 3 Annales de Bretagne et des Pays de l'Ouest 26, 27.

60 Félix J., 'Comprendre l'opposition parlementaire, Le Parlement de Paris face aux réformes de Silhouette (1759)', (2011) ( 15)1 Parlement(s), Revue d'histoire politique 32; Daireaux L., 'Le parlement de Normandie et lédit de Nantes: une bataille de dix ans (1599-1610)' (2015) (122) 3 Annales de Bretagne et des Pays de l'Ouest 77 vd.

61 Félix 34.

62 Chénon 38.

63 "Les parlements sont établis par le roi pour être les juges des peuples et non leurs représentants, les officiers du roi et non les députés de la Nation."

64 Swann 22-23. 
Başka bir fikre göre, parlemanlar ve krallık arasındaki gerilim hâkimlerin mesleki çıkarlarını koruma amacından kaynaklanmaktadır ${ }^{65}$. Buna karşın parlemanlar sayesinde "milli egemenlik (souveraineté national)" anlayışının yerleştiğini ifade etmek mümkündür ${ }^{66}$. Bu sebeple ilgili vergi kanunlarına veya yeni vergilere karşı muhalefet, konunun siyasi karakterinden dolayı, hukuki gerilimin hüviyetini bir anda değiştirebilecek karaktere sahiptir. Breen'in aktardığına göre 18. yüzyılın başlarına doğru yalnızca parleman hâkimlerinde değil; daha alt derecelerdeki baillage ve prévôté hâkimlerinde de adalet düşüncesi ve kamu yararını önceleyen bir yargı anlayışı gelişmiştir ${ }^{67}$.

Doktrinde görüş birliği olmasa da evrimci teoriyi kabul eden yeni sayılabilecek eğilim, parlemanların belirli bir demokrasi kültürü sağlamada önem arz eden kurumlar olduğunu savunmaktadır ${ }^{68}$. Parlemanların bu etkisini kral lehine dengeleyen kurum ise, temyiz yargılaması karakterine sahip Kralın Konseyi (Conseil du roi) olmuştur ${ }^{69}$.

\section{ESKI REJIMDEN YENI REJIME TEMYIZ MAHKEMESININ DÖNÜŞÜMÜ}

\section{A. KRALIN KONSEYI (CONSEIL DU ROI)}

Conseil $d u$ roi, modern öncesi dönemde Fransız hukukundaki temyiz benzeri karakter taşıyan en önemli kurumdur. Zira Conseil $d u$ roi, yalnızca bazı sınırlı hususlar bakımından ilk derece yargılaması olarak görev yapmakta olup asıl görevi, parleman kararlarının kanun yolu denetimini yürütmektedir. Diğer taraftan Conseil $d u$ roi, modern temyiz mahkemeleri gibi yargılamanın konusunu oluşturan kararın hukuka aykırı olduğunu tespit ettiği hâllerde kararı bozup derece mahkemesine göndermektedir ${ }^{70}$. Bu iki unsur, Conseil du roi kurumunun Fransı hukukunun modern öncesi döneminde temyize en yakın kurum olduğunu göstermektedir ${ }^{71}$. Hatta bazı görüşlere göre Conseil du roi, açık bir şekilde Fransız Temyiz Mahkemesi’nin (Cour de cassation) selefidir ${ }^{72}$. Conseil $d u$ roi, hem derece hem de temyiz benzeri bir yargılama yapan parlemanların (parlements) nüfuzunu zayıflatmak; hukukun monarkın uhdesindeki bir kurum tarafından yeknesaklaştırılmasını sağlamayı amaçlamaktadır ${ }^{73}$.

65 Örneğin Rouland, parlemanların denetim yetkisine yönelik taleplerinin temelinde kendi yetkilerini düzenleyen emirnamelerin uygulanmasını engelleme düşüncesinin yattığını belirterek bu anayasacılık faaliyetinin aslında parlemanların çıkarından kaynaklandığını ifade etmektedir (Rouland 378).

66 Swann 22.

67 Breen 372.

68 Bu konuda bkz. Bidouze F., 'İntroduction. Quelle culture politique en héritage?’ (2011) (15) 1 Parlement(s) Revue d'histoire politique 11.

69 Öztek S., 'Temyiz Kanun Yolunun Tarihçesine İlişkin Bazı Tespitler' (2015) (21) 2 Prof. Dr. Mehmet Âkif Aydın’a Armağan MÜHF-HAD 125.

70 Barbiche, B., 'Le Conseil du roi dans tous ses états: Questions de vocabulaire' (1999) (52) (3) La Revue Administrative 21.

71 Barbiche, Bernard, 'Les attributions judiciaires du Conseil du roi' (2010) (29)3 Histoire, économie \& société 11.

72 Barbiche, Conseil 21.

73 Öztek, Tarihçe 125; Hamscher, Albert N., The Conseil Privé and the Parlements in the Age of Louis XIV: A Study in French Absolutism (Transactions of the American Philosophical Society 1987). 
Modern öncesi dönemde Konsey’in gelişimi Fransảnın siyasi yapısıyla doğrudan bağlantılı olmuştur. Öyle ki başlangıçta aristokratlardan oluşan ve feodal bir kurum izlemini veren Konsey, siyasi sistemin merkezileşmesiyle birlikte idari-bürokratik bir yapıya dönüşmüştür ${ }^{74}$. Konsey, Orta çağda önemli bir etkiye sahip olmaktan uzaktır ${ }^{75}$. Buna karşın siyasi yapının merkezileşerek monarkın güçlendiği ve nüfusun artışına paralel olarak idari ve yargısal işlerin sayısının hızlıca yükseldiği modern öncesi dönemde Konsey'in etkisi de artmıştır. Konsey'in içeresindeki özel birimlerle birlikte kurumsallaşması esasen 14. Louis dönemini içine alan 1661 ve 1664 yılları arasında gerçekleşmiştir ${ }^{76}$.

Konsey, birçok alt kuruldan oluşmaktadır. Kurulların önemli bir çoğunluğu esasen idari karakterdedir. Şansöyle başkanlığında toplanan Conseil d’en haut, mali ve iktisadi işleri yürüten Conseil des finances, Conseil des dépêches bu alt kurullara örnek olarak verilebilir ${ }^{77}$. Konsey, kendi içerisinde seksiyonlara ayrılmakta olup kral, bu mini konseylerin niteliğine göre toplantıya katılıp katılmama kararı alabilir ${ }^{78}$. Kralın yargısal işlerin görüşüldüğü Conseil des parties oturumlarına genelde katılmamakla birlikte idari işlerin görüşüldüğü diğer Konsey toplantılarına katıldığı belirtilmektedir ${ }^{79}$. Kralın katılmadığ oturumlarda da kararlar kral adına alınır. Zira Konsey tüm birimleriyle birlikte kralın mutlak iradesini yansıtmaktadır ${ }^{80}$. Bu sebeple șeklen kurullara ayrılmış gibi görünse de Konsey’in bütünlüğü ilkesi geçerlidir ${ }^{81}$. Konsey'in iç işleri ve yönetim alanlarında uzmanlaşmasına yönelik kurumsal yapısı 17. yüzyılın ortasından sonra belirginleşmeye başlar ${ }^{82}$. Öyle ki senyörlerin gücünün azaldığı bu dönemlerde Konsey, dış işleri bakanı, maliye bakanı gibi idari yöneticilerden oluşmaktadır ${ }^{83}$.

Kralın Konseyi’nin yargı işlerine bakan bölümü ise Conseil des parties veya Conseil privé olarak adlandırılmaktadır. Böylelikle Conseil privé, yaptığı işler bakımından idari bir karaktere sahip olan Conseil $d u$ roi içerisindeki kazai kurulu oluşturmaktadır ${ }^{84}$. Conseil $d u$ roi içindeki bu yargısal kurumlara müracaatın konusu yalnızca parlemanların kararları olabilir ${ }^{85}$. Eski rejim döneminde kanun yolu mahkemesi olarak gösterilen présidaux, parlemanlar gibi mahkemeler istisnai hâllerde ilk derece yargılaması yapabilmektedir. Ancak Conseil du roi yalnızca parleman kararlarını incelediği için bu mahkemelerden ayrillır ${ }^{86}$.

74 Chénon, Histoire, Tome I 322; Saupin G., La France à l’époque moderne, (4e édition, U Histoire 2020) 95.

75 Guenée B., 'Le Conseil du roi au Moyen Age' (1999) (52) 3 La Revue administrative 5.

76 Barbiche 10.

77 Mousnier R., Le Conseil du Roi de Louis XII à la Révolution (PUF1970) 5, 6.

78 Örneğin Louis XIV'un, en yüksek devlet işlerinin görüşüldüğü Conseil d'En Haut toplantılarına mutlaka başkanlık edildiği ifade edilmektedir. Bunun dışında mali işlerin görüşüldüğü Conseil des Depeches'in toplantılarına krallığın en yüksek bürokratı şansölye (chancelier) başkanlık etmekteydi (Antoine, M., 'Qui entrait au Conseil du Roi?' (1999) 53(3) La Revue Administrative 71).

79 Thireau J.L., 'Le Conseil du roi au XVI e siècle' (1999) (52) 3 La Revue administrative 18.

80 Thireau 14.

81 Pagès G., 'Le Conseil du Roi sous Louis XIII' (1937) (12) 29 Revue d'histoire moderne 296.

82 Thireau, Jean-Louis, 'Le Conseil du roi au XVIe siècle' (1999) (3)3 La Revue administrative 11.

83 Hamscher 6.

84 Pagès 300; Barbiche, İnstitutions 290; Mousnier R., 'Le Conseil du Roi de la mort de Henri IV au gouvernement personnel de Louis XIV’ (1947) (1) Etudes D’histoire Moderne Et Contemporaine 31; Barbiche, Attributions 10; Guenée 6.

85 Mousnier, Gouvernement 33.

86 Mousnier, parlemanlar ve Conseil du roi arasında yetki çekişmesinin olduğunu kaydetmektedir. Parlemanlara göre, 
Conseil $d u$ roi, parlemanın kararlarını ya onar ya da bozar ${ }^{87}$. Daha ziyade bir istinaf mahkemesine benzeyen parlemanların aksine, Conseil du roi istisnai hâllerin dışında kararı kaldırıp yeni bir karar veremez. Bu sebeple Conseil du roi, eski rejimin modern hukuktaki unsurlarını taşıyan yegane temyiz mahkemesi karakterini taşımaktadır ${ }^{88}$.

Kararın Conseil du roi tarafından bozulması üzerine dosya, kararı veren parlemana veya başka bir parlemana gönderilir. Bununla birlikte bazı istisnai hâllerde Conseil privé (Conseil des parties), yargılamayı yeniden yapmaktadır ${ }^{89}$. Yeniden yargılama prosedürü (évocation), üç hâlde söz konusu olur. Birinci hâlde Conseil privé, bir yüksek mahkeme olarak kararı veren parlemanın tarafsızlığından veya bağımsızlı̆̆ından şüphe duyulacak bir hâli tespit etmektedir (évocation de justice). İkinci hâlde taraflardan birinin talebi üzerine yeniden yargılama yapılmasında hukuki menfaat görülmektedir (évocation de grâce). Üçüncü ve istisnai bir hâlde ise doğrudan doğruya kralın müdahalesiyle yeniden yargilama yapılmaktadır (évocation de propre mouvement $)^{90}$.

Modern anlamda temyiz (cassation) ise yeniden yargılamaya göre daha geç gelişmiştir. Başlarda temyiz sebepleri doğrudan doğruya Konsey tarafından tespit edilmektedir. Bu sebeple en başta temyiz sebepleri konusunda belirli ilkeler bulunduğu ifade edilemez. Ancak daha sonra modern hukuktaki temyize benzer şekilde "kanuna aykırılık (emirnamelere aykırılık)" temyiz sebebi olarak kabul edilmiştir ${ }^{91}$. 18. yüzyılda kanuna aykırılık dışında usul kurallarına aykırılık, görevsiz mahkemenin davaya bakması, yetki aşımı ve aynı konuda verilen iki kararının bulunması da birer temyiz sebebi kabul edilerek modern temyizin temelleri atılmıştır ${ }^{92}$. Özellikle 17. yüzyılda Conseil privé tarafından gerçekleştirilen ön inceleme prosedürleri, Konsey’in içindeki adalet bürokrasinin işleyişi gibi hususlar yerleşiklik kazanmaya başlar ${ }^{93}$.

Konsey yargılamalarının 17. yüzyıldan itibaren gösterdiği bu gelişim esasen parleman yargılamalarının kurumsallaşmasıyla da alakalıdır. Conseil privé, parleman kararlarına karşı müracaat edilen bir kurum olduğu için parlemanların kralın emirnamelerine aykırı olarak vermiş olduğu kararları kral adına denetleme imkânına sahiptir" değerlendirilmesi de bu gelişmelerle uyumludur" ${ }^{95}$. Temyiz mahkemesi benzeri bir karaktere sahip

Conseil du roi’nın oturumda kral bulunmadan aldığı kararlara parlemanların oturumda kral bulunmadan alınan kararları (lits de justice) hukuken eşit değere sahiptir. Bu sebeple Conseil du Roi’nın parlemanların kararlarını bozması mümkün değildir (Mousnier, Gouvernement 33).

87 Rouland 388

88 Godin X., 'La procédure de cassation au XVIIIe siècle' (2010) (3) Histoire, économie \& société 20.

89 Hamscher, temyiz mahkemesine benzer bir yapıya sahip olan Conseil privẻnin yeniden yargılamayı yaptığı hâllerin konseyin dağınık bir yapıya sahip olmasına sebep olduğunu ifade etmektedir. Zira yeniden yargılama kararı, parlemanlara olan güvensizlik sebebiyle keyfi bir şekilde alınabilmektedir (Hamscher 19).

90 Martinage-Baranger R. 'Les idées sur la Cassation au XVIII e.' (1969) (47) Revue Historique De Droit Français Et Étranger 250; Barbiche, İnstitutions 298.

91 Barbiche, İnstitutions 299.

92 Martinage-Baranger 259.

93 Hamscher 89; Mousnier, Conseil 18.

94 Martinage-Baranger 248.

95 Nitekim konseyin karakteri, Fransızca "justice retenue" olarak ifade edilmektedir. Retenue, yeniden ele almak anlamina gelen "retenir" fiilinin sıfat hâlidir. Dolayısıyla bu kavram, adaletin kralın kendisi adına karar alan en yetkili kurumu 
olan Conseil privé, Fransız hukukunda temyizin olağanüstü kanun yolu karakteri taşıdığına yönelik fikirlerin temelini teşkil eder. Zira baillage, présidiaux, parlemanlar gibi birçok mahkeme esasen derece yargılaması yaptığı için istinafa yakın birer kanun yolu mercidir. Hâlbuki doktrinde haklı olarak ifade edildiği üzere Conseil privé, bir son derece mahkemesi değildir. Zira Konsey, derece yargılaması yapmamakta; hukuka aykırı gördüğü kararları bozmakla yetinmektedir ${ }^{96}$. Konsey’in esasa ilişkin inceleme yapamaması, belirli bir uygulamanın sonunda yargı teşkilatına ilişkin anayasal bir ilke olarak kabul görmeye başlamıştır ${ }^{97}$.

Konsey'in yaptığı yargılamayı modern Fransız hukukundaki temyize yaklaştıran başka bir husussa müracaatın etkisinde görülmektedir. Zira modern temyizde kabul edildiği gibi, parleman kararlarına karşı Konsey’e müracaat edilmesi kararın icrası engellememektedir ${ }^{98}$.

Tüm bunlara rağmen Konsey'de yapılan yargılamanın modern hukuktaki temyiz mahkemesi yargılaması kadar kapsamlı olmamaktadır. Bir kere bürokratik prosedürünün yoğunluğundan dolayı Konsey’e müracaat zorlaşmaktadır. Ayrıca parleman kararlarına karşı Konsey’e müracaat eden taraf, 1667 tarihli emirnameye göre 450 kuruş (livres) değerinde harç benzeri bir bedel ödemektedir. Şayet talebi reddedilirse bu bedelin üçte ikisi krallığa; geri kalanı ise karşı tarafa verilmektedir ${ }^{99}$. Ancak 17. yüzyılın sonlarına doğru Conseil privé teşkilatına mensup adli bürokrasi bu uygulamayı tartışmaya açmıştır. Zira Conseil privé, adli teşkilattaki son mahkeme olup Konsey yargılamasında bireysel menfaat kadar kamu yararı da bulunmaktadır ${ }^{100}$.

Konsey'in bir parleman kararının bozabilmesi için kanuna açık bir aykırılığı aradığı anlaşılmaktadır ${ }^{101}$. Zira belirtildiği gibi Konsey kural olarak esasa ilişkin bir yargılama yapmamaktadır. Her ne kadar temyiz yargılamasının gelişmesine hizmet etse de Conseil privé yargılamalarının modern hukuktaki yargılamalara göre önemli eksiklikler barındırdığı ifade edilmektedir. Öyle ki Konsey’in kaç üyeyle toplandığı belli olmadığı gibi Konsey’e yürütme organın başı olan şansölye tarafından başkanlık edilmekte; Konsey'in kararlarının gerekçeli olması da aranmamaktadır ${ }^{102}$.

\section{B. MODERN TEMYIZ MAHKEMESI TRIBUNAL DE CASSATION VE COUR DE CASSATION}

İhtilal öncesi temyiz kurumu olan Konsey'in (Conseil privé) amaç ve işlevi, kralın emirnamelerinin mutlak surette uygulanmasını sağlamaktır ${ }^{103}$. Bu sebeple Conseil privé tam anlamıla bir aristokrasi

olan konsey tarafından yeniden ele alınması manasına gelmektedir (Martinage-Baranger 251; Thireaus. 18; Barbiche, Attributions 17). Mademki hukukun kaynağı kralın iradesidir. O hâlde parlemanlara delege edilen adalet, hukukun yaratıcısı kral tarafından denetlenmelidir (Chaline O. , 'Ouverture' (2010) (29) 3 Histoire, économie \& société 3; Martinage-Baranger 259).

96 Godin 20.

97 Martinage-Baranger 266.

98 Martinage-Baranger 265.

99 Hamscher 98.

100 Hamscher 100.

101 Godin 23.

102 Chénon 56.

103 Öztek, Tarihçe 125-126. 
kurumudur. Hâlbuki ihtilal sonrası kurulan yeni Temyiz Mahkemesi ve sistemi, hukuk süjelerinin yargıya erişimine kapsamına alan modern bir kurum olacaktır ${ }^{104}$. Öncelikle 1790 yılında Temyiz Mahkemesi'nin Tribunal de cassation adıyla kurulmasıyla içtihat birliğini sağlamak kadar hukuk süjelerinin taleplerini cevap veren; bu yönüyle aristokrasinin Conseil privé kurumundan çok farklı bir karaktere sahip olan bir Temyiz Mahkemesi ortaya çıkmıştır. İkinci dönüşümse halkın temsili iradesini, teknik hukuk bilgsinin önüne koyan yasama yorumu (référé législatif) kurumunun ortadan kaldırıldığg 1837 yılında gerçekleşir. Böylece hukuk süjelerinin müracaatına açık ve yasamadan bağımsız modern bir Temyiz Mahkemesi’nin tesisi söz konusu olabilmiştir ${ }^{105}$.

Fransız Temyiz Mahkemesi, 27 Kasım-1 Aralık Kanunu ile 1790 yılında kurucu meclis tarafından “Tribunal de cassation” adıyla kurulmuştur ${ }^{106}$. Esasen Temyiz Mahkemesi’nin temelini eski rejimdeki Conseil du roi oluşturmaktadır. Öyle ki dört bölüme ayrılan Konsey’in yargılamadan sorumlu bölümü Conseil des parties, parlemanlar tarafından alınan kararların kralın emirnamelerine uygunluğunu denetlemekteydi. Conseil des parties, 1790 yılına kadar kanunların düzgün uygulanmasının denetiminde önemli bir role sahipti. Ancak Consel des parties ve Cour de cassation arasında temel bir fark bulunmaktadır. Modern yüksek mahkemelerden farklı olarak Conseil des parties, bütün hukukun monarkın iradesinden kaynaklandığı modern öncesi dönemin bir ürünüdür ${ }^{107}$.

Kanun koyucunun önceliklerinden biri de 18. yüzyılın aydınlanma filozoflarından miras kalan dönemin yeni fikri güçler ayrılığını tesis ederek hukuk birliğini sağlayacak bağımsız bir mahkeme kurmak olmuştur. Bu sebeple Conseil des parties uygulamasından farklı olarak yeni kurulan Tribunal de cassation uyuşmazlığın esasını incelemez ${ }^{108}$. Zira Temyiz Mahkemesi’nin asıl görevi kanunların bütün Fransa coğrafyasında aynı şekilde uygulanmasını sağlamaktır. Temyiz Mahkemesi’nin siyasi karakterdeki bu yapısı, 19. yüzyılın başlarında yargısal görevinin önüne geçmektedir ${ }^{109}$. Nitekim Tribunal de cassation, öncelikle yasama meclisinin bir organı olup yegâne görevi mahkemeler tarafından kanunların yeknesak biçimde uygulanmasıdır ${ }^{110}$. Temyiz mahkemesi ilerleyen süreçte hukuki yeknesaklığın yanı sıra bireyin sübjektif hakkını gerçekleştirmek olan modern temyizin amacına $^{111}$ uygun bir yargılama yapacaktır.

Tribunal de cassation, 48 hâkimden ve üç bölümden müteşekkildi. Daha sonra ve dilekçeler bürosu (Bureau des requêtes), temyiz bölümü (Section de cassation) kendi içinde hukuk ve ceza olmak

104 Weber J.F., 'L'Accès au Juge de Cassation et Le Traitement des Pourvois par La Cour de Cassation Française', iç Guillaume Drago, Bénédicte Fauvarque-Cosson ve Marie Goré (edr) L’accès au juge de cassation Colloque du 15 Juin 2015 (Collectif 2015) 61; Cadiet, Ouverture 19.

105 Brenner C., iç 'Les Différentes missions du juge de cassation' iç Guillaume Drago, Bénédicte Fauvarque-Cosson ve Marie Goré (ed) Laccès au juge de cassation Colloque du 15 Juin 2015 (Collectif 2015) 31, 32.

106 Picca G. ve Cobert L., La Cour de Cassation (PUF 1986) 13.

107 Bellet P., 'France. La Cour de cassation, La cour judiciaire suprême Enquête comparative' (1978) (30)1 Revue internationale de droit comparé 193.

108 Bellet 193.

109 Burgelin J.F., 'L’Organisation interne de la Cour de cassation favorise-t-elle l'élaboration de sa jurisprudence' iç Nicolas Molfessis (edr) La Cour de cassation et L'Élaboration du Droit (Economica 2004) 23.

110 Scheyven C., Traité pratique des pourvois en cassation (Bruylant-Christophe \& Compagnie 1866) 20; Chénon 3.

111 Yıldırım K., Hukuk Devletinin Gereği: İstinaf (Nesil Matbaacılık 2000) 13. 
üzere iki bölüme ayrılmıştır ${ }^{112}$. Mahkemenin teşkilatına ilişkin detaylı sayılacak düzenlemeler kuruluştan yaklaşık on yıl sonra 18 Mart 1800 tarihli Mahkemelerin Teşkilatı̉na Dair Kanun'la ${ }^{113}$ tesis edilmiştir ${ }^{114}$. Kanun'a göre Tribunal de cassation Paris’te bulunur (m. 58). Yüksek Mahkeme, her birinde on altı üye bulunan üç daireden oluşmaktadır. Dairelerden biri başvuruların kabul edilebilirliğini inceler. Diğer iki daireden biri ceza dairesi; diğeri ise hukuk dairesi olarak görev yapar (m. 60). Aynı maddeye göre müracaatları inceleyen daire (chambre des requêtes) başvuruların Temyiz Mahkemesi tarafından incelenmesi gerektiğini düşünüyorsa temyiz başvurusunu ilgili daireye göndermektedir. Aksi taktirde müracaatı, görevli olduğunu düşündüğü mahkemeye gönderir ( $\mathrm{m}$. 60). Daire başkanları, ilgili daire tarafından üç yıllı̆̆ına seçilir (m. 65). Aynı şekilde bütün üyeler Temyiz Mahkemesi’nin Birinci Başkanı’nı üç yıllığına seçer (m. 62). Kanunla Fransız hukukundaki modern temyiz teşkilatı ve yargılamasına esas teşkil eden hükümler de öngörülmüştür. Örneğin İnsan Hakları Avrupa Mahkemesi’nin ihlal kararlarına kadar varlığını sürdürecek olan hükümet komiserliği (commisaire du gouvernement) ${ }^{115}$, bu Kanunla detaylı şekilde düzenlenmiştir. Diğer taraftan bozma kararındaki sebepler çerçevesinde karar vermeyen derece mahkemesinin bu kararına karşı temyize müracaat edildiğinde, karar Temyiz Mahkemesi’nin bütün daireleri üyelerinden oluşan kurul tarafından incelenir (m. 78) ${ }^{116}$. Esasen benzer bir hüküm Fransız Adli Teşkilat Kanunu’nda bulunmaktadır. Kanun’a göre derece mahkemesi bozma kararındaki sebeplerin aksi yönünde karar verir ve bu karara karşı da temyize müracaat edilirse inceleme, Genel Kurul (Assemblée plénière) tarafindan yapilır (COJ Art. L. 431-6).

Tribunal de cassation 1804 yllında isim değişikliği yaşamış ve Cour de cassation adını almıştır ${ }^{117}$.

Fransız İhtilali ve arka planındaki düşüncenin halk iradesine verdiği önem gereği esasen Cour de cassation 1837 yılına kadar yasamadan ayrı düşünülmüş bağımsız bir mahkeme hüviyetine sahip olmamıştır ${ }^{118}$. Zira bu tarihe kadar Fransız hukukunda yasama yorumu (référé législatif) kabul edilmiştir. Yasama yorumu (référé législatif), kökeni eski rejime dayanan ve monarkın kanunların uygulanması ve yorumlanması üzerindeki mutlak yetkisini gösteren önemli bir kurumdur ${ }^{119}$. Yarg1 Teşkilatı’na Dair 16-24 Ağustos Kanunlarının ${ }^{120}$ 12. Maddesine göre: "Hâkimler normatif nitelikte karar veremezler. Ancak gerek kanunların yorumlanmast gerekse de yeni kanun yapılması için lüzumlu buldukları herhâlde yasama meclisine müracaat ederler." Genel Kurul daha sonra 30 Temmuz

112 Bellet 194.

113 Loi sur l'organisation des tribunaux.

114 Loi du 27 ventôse an VIII.

115 Karar için bkz. İHAM, İmmeubles Groupe Kosser/Fransa, 21 Mart 2002, 20-28. Paragraflar (https://hudoc.echr.coe.int, e.t. 16.10.2020).

116 Crépon T., Pourvoi en cassation en matière civile, 1er Tome, (Librairie du Receuil Général des Lois et des Arrêts 1892) 85.

117 Belda J.B., Du discours sur l’office de la Cour de cassation, (Lextenso 2018) 28.

118 Vincent, Jean/Guinchard, Serge, Instutions Judiciaires, Organisations, Juridictions, Gens de justice, Editions dalloz, Paris 2005603.

119 Hufteau Y.L, Le Référé législatif et les pouvoirs du juge dans le silence de la loi (PUF 1965) $9 \mathrm{vd.}$

120 Loi des 16-24 août 1790 sur l'organisation judiciaire. 
1828 tarihli Kanunla tekrar düzenlenmiştir. Kanun’a göre ikinci temyiz müracaatı, bütün daireler (chambres réunies) tarafından incelenir ${ }^{121}$.

Buna göre Temyiz Mahkemesi’nin karşısına çıkan yorum problemlerinde yasama meclisine müracaat etmesi zorunludur ${ }^{122}$. Yasama yorumu, dönemin halk iradesini öne ç1karan ruhundan kaynaklanmaktadır ${ }^{123}$. Bu yönüyle kurum dönemin yasama meclisini ön plana çıkaran ideolojik yapısını yansıtır. Yasama yorumunun (référé législatif) seyrinin de pek istikrarlı olduğu ifade edilemez. Zira kurum, Temyiz Mahkemesi'nin Tribunal de cassation ismiyle kurulduğu tarih olan 1790 yılından 1800 yılına kadar on yıl süreyle yürürlükte kalmış; 1800 yılında 18 Mart 1800 tarihli Mahkemelerin Teşkilatı'na Dair Kanun'la kaldırılmıştır. Ancak 16 Eylül 1807 tarihli Kanun'la yeniden tesis edilmiştir ${ }^{124}$. Nihayet yasama yorumu 1 Nisan 1837 tarihli Kanun’la tamamen kaldırılmıștır.

Temyiz Mahkemesi’nin yargılamasına ilişskin esasların gelişmesi de tıpkı kararlarının normatif etkisinin gelişmesi gibi zaman almıştır. Bu hususta 20 Nisan 1810 tarihli Adli Teşkilat ve Yarg1 Hizmetine ilişkin Kanun'a ${ }^{125}$ değinmek gerekmektedir. Kanun'un 7. maddesine göre yargı hizmeti mahkemelerin kararlarıyla temin edilir. Mahkeme kararları, ancak kanunlara açık aykırılık hâlinde Temyiz Mahkemesi tarafından bozulabilir ${ }^{126}$. 19 Mart 1810 yılında ise Fransız Mahkemesi hâkimlerine "conseiller" ismi verilmiştir.

18 Mart 1800 tarihli Mahkemelerin Teşkilatı'na Dair Kanun'la tesis edilen yapı uzun yıllar boyunca aynı şekilde devam etmiştir. Ancak temyiz müracaatlarındaki artışlar ve hukuk sistemindeki değişiklikler daire sayısının artmasına sebep olmuştur ${ }^{127}$. Öncelikle 12 Kasım 1938 tarihli Kanun Hükmünde Kararname ile İş ve Sosyal Güvenlik hukuku dairesi (Chambre sociale) kurulmuştur. 23 Temmuz 1947 tarihli Kanunla ise temyiz müracaatlarına ilişkin ön incelemeyi yürüten Chambre des requêtes kaldırılmış ve Ticaret Hukuku Dairesi (Chambre de commerce) kurulmuştur. Böylece 1947 tarihinde Temyiz Mahkemesi'nde bir adet ceza, bir adet medeni hukuk (chambre civile), bir adet iş ve sosyal güvenlik dairesi (chambre sociale) ve bir adet ticaret dairesi (chambre commerciale) bulunmaktadır. Buna karşın ek iki medeni hukuk dairesi 21 Temmuz 1952 ve 3 Temmuz 1967 tarihlerinde kurularak medeni hukuk dairesi sayısı üçe çıkarılmıştır. Bu son reformla Temyiz Mahkemesi'nin dairelerine nihai hâl verilmiştir ${ }^{128}$. Buna göre 1967 tarihinden günümüze kadar Fransız Temyiz Mahkemesi’nde bir ceza dairesi (chambre criminelle), üç medeni hukuk dairesi (chambres civiles), bir ticaret (chambre commerciale) ve bir iş ve sosyal güvenlik dairesi (chambre sociale) bulunmaktadır.

121 Chénon 11-12.

122 Belda 27.

123 Royer, J.P. ve Derasse N., Alinne J.P., Durand B., Jean J.P., Histoire de la justice en France, (5e édition, PUF 1995) 252.

124 Lanzara D., Le pouvoir normatif de la Cour de cassation à l'heure actuelle (LGJD 2017) 2.

125 Loi du 20 avril 1810 sur l'organisation de l'ordre judiciaire et l'administration de la justice.

126 Crépon 87.

127 Cadiet, L., 'Ouverture', iç Réformer La Cour de Cassation, Le Projet de Réforme en Débat, Actes du colloque du 11 avril 2019 (IRJS Editions 2019) 20.

128 Cadiet, Ouverture 20. 
Dilekçe Dairesini (Chambre des requêtes) kaldırarak bir ticaret hukuku dairesini kuran 47-1366 sayılı ve 23 Temmuz 1947 tarihli Temyiz Mahkemesi’nin Teşkilatı ve Yargılama Usulüne Dair Kanun, Yüksek Mahkeme teşkilatına dair detaylı hükümler sevk etmiştir ${ }^{129}$. 23 Temmuz 1947 tarihli bu Kanunla temyiz müracaatlarını kesin olarak incelemekle görevli Genel Kurul (Assemblé plénière) kurulmuştur (m. 6). 3 Temmuz 1967 tarihli Kanunla tetkik hâkimler (conseiller référendaires) Temyiz Mahkemesi’nin teşkilatına dâhil edilmiştir. 79-9 sayılı 3 Ocak 1979 tarihli Temyiz Mahkemesi’nin Teşkilatı’na Dair Bazı Değişiklilere İlişkin Kanun'la Temyiz Mahkemesi’nin yargılama prosedüründe bazı değişiklikler yapılmıştır. Hâlen yürürlükte olan Fransız Adli Teşkilat Kanunu ile Yüksek Mahkeme’nin yapısı ve yargılama usulüne ilişkin hususlar önemli ölçüde korunmuştur.

\section{SONUÇ}

Modern Fransız Temyiz Mahkemesi Cour de cassation, Fransız hukukunda bin yıla yakın bir geçmişi olan adalet teşkilatı ve kanun yolu düşüncesinin nihai noktasıdır. Ancak ihtilal öncesi adli teşkilat ile modern Temyiz Mahkemesi arasında süregelen bir ilişki olduğunu iddia etmek kolay değildir. Öncelikle Orta çağ Fransa’sında dağınık ve birçok imtiyazlı grup için ayrı düzenlemeler getiren bir yargı teşkilatı söz konusudur. Yargı teşkilatındaki ilk ayrım kralın toprakları ile krala ait olmayan çeşitli senyörlerin toprakları üzerindeki mahkemeler arasındadır. Prévôté Kralın topraklarındaki ilk derece mahkemesidir. İlk derece mahkemesi hâkimi Prévôt ise genelde seküler hukuku uygulayan idari ve adli bürokrattır. Prévôt yalnızca kralın topraklarında görevli olup senyörlere ait topraklarda meydana gelen adli uyuşmazlıklara bakamamaktadır. Bu uyuşmazlıklar yalnızca senyörlerin görevlendirdiği senyör mahkemeleri tarafından gerçekleştirilir. Diğer ayrımsa seküler hukuk ve dini hukuk bakımından yapılmaktadır. Dini alana giren uyuşmazlıklarda kilise yargımalar görevlidir.

Prévôté kararlarına karşı ikinci derece mahkemesi olarak baillage mahkemelerine müracaat edilebilmektedir. Baillage kararlarına karşı ise üçüncü derece yargılamasını yürüten présidiaux mahkemelerine müracaat edilmesi mümkündür. Ancak ceza davaları bakımından ilgili kararlara kanun yoluna müracaat açık olsa da hukuki uyuşmazlıklarda değere bağlı kanun yolu sistemi geçerli olduğu için her karara karşı ilgili mahkemelerde kanun yolu başvurusu yapmak mümkün olmamaktadır. İlgili yargı çevrelerinin üzerindeki son merci ise parlemanlardır (Parlemants provinciaux). Parlemanlar, esasen birer derece mahkemesidir. Ancak modern öncesi döneme yaklaştıkça kendi yargı çevrelerindeki en yüksek derece mahkemesi sıfatını haiz olan ve kamu düzenini sağlamak gibi önemli idari işlevleri de bulunan parlemanlar ve monark arasında politik bir gerilim baş göstermeye başlamıştır. İşte bu politik gerilim eski rejim döneminde temyiz benzeri tek kurum olan Kral’ın Konsey'i (Conseil du roi) içerisindeki Conseil des parties alt konseyinin güçlenmesine yol açmıştır. Conseil des parties, hukuk süjelerinin hakkının temininden çok kralın emirnamelerinin parlemanlar tarafından uygulanmasını sağlamayı amaçlamaktadır. Conseil des parties, kural olarak derece yargılaması yapmamakta, kararların yalnızca krallık emirnamelerine uygun olup olmadığını denetlemekte ve kararın bozulması hâlinde dosyayı son derece mahkemesi olan parlemana göndermektedir. Elbette İmparatorluğun başkenti olan Paris’te bulunan ve yalnızca

129 Ferrand F., Cassation française et révision allemande (PUF 1993) XIX. 
değeri yüksek uyuşmazlıklara bakan Konsey’e ulaşmak hukuk süjeleri açısından kolay olmamakta, müracaatlar genelde ekonomik durumu çok iyi olan kimseler tarafından gerçekleştirilebilmektedir.

Fransız İhtilali genel olarak hukuka ve yargılama hukukuna eski rejim döneminden farklı bir bakış getirmiştir. Bununla birlikte bu farklılaşmanın kimi hâllerde zayıf olduğunu belirtmek gerekmektedir. Zira eski rejim döneminde Conseil des parties, nasıl ki monarkın emirnamelerine uyulup uyulmadığını denetmekteyse 1790 yılında kurulan Tribunal de cassation da hukuk süjesinin menfaatinden ziyade yasa koyucunun iradesi olan kanunun derece mahkemeleri tarafindan yeknesak uygulanıp uygulanmadığını öncelemektedir. Yasama yorumunun tamamen kaldırıldı̆̆ı döneme kadar Temyiz Mahkemesi’nin kararları soyut normatif kural koyan içtihat karakterinde olamamıştır.

Tribunal de cassation ilk kurulduğunda dilekçeler ve temyiz dairelerinden oluşmaktadır. Temyiz daireleri ise hukuk ve ceza daireleri olarak ikiye ayrılmaktadır. Belirli bir döneme kadar mahkemenin hukuki yeknesaklığı sağlamayı hedefleyen siyasi görevi, hukuk süjesinin hakkını gerçekleştirmeyi amaçlayan hukuki görevinin önüne geçmiştir. Mahkeme 1804 yılında bugünkü Fransız Temyiz Mahkemesi olan Cour de cassation adını almıştır. Daha sonraki süreçte yasama yorumunun (référé législatif) kaldırılmasıyla birlikte Cour de cassation, gerçek bir Temyiz Mahkemesi hüviyetine kavuşmuştur. Sonraki her süreçte gerek müracaatlarıyla orantılı olarak daire ve hâkim sayısındaki artışlar, gerek doktrinsel yapıya sahip kurumların inşası gerekse de kanun değişiklikleriyle beraber mahkemenin bazı hâllerde esasa girip hüküm verebilme imkânı, Temyiz Mahkemesi’ni bireyin hakkını temin eden bir kuruma dönüştürmüştür.

Her ne kadar aralarında önemli farklılıklar bulunsa da modern öncesi Temyiz Mahkemesi Conseil des parties, belirli bir temyiz anlayışı tesis ederek modern Temyiz Mahkemesỉnin (Tribunal de cassation ve Cour de cassation) gelişimine katkıda bulunmuştur.

\section{KAYNAKÇA}

Antoine M., 'Qui entrait au Conseil du Roi?' (1999) 53(3) La Revue Administrative s. 71-76.

Barbiche B., 'Le Conseil du roi dans tous ses états: Questions de vocabulaire' (1999) (52) (3) La Revue Administrative s. 20, 26 (Conseil).

Barbiche B., 'Les attributions judiciaires du Conseil du roi' (2010) (29)3 Histoire, économie \& société s. 9, 17 (Attributions).

Barbiche B., Les institutions de la monarchie française à lépoque moderne XVIe-XVIIIe siècle, (Presses Universitaires de France 2012).

Belda J.B., Du discours sur l'office de la Cour de cassation, (Lextenso 2018).

Bellet P., 'France. La Cour de cassation", La cour judiciaire suprême Enquête comparative' (1978) (30)1 Revue internationale de droit comparé s. 193, 215.

Bidouze F., 'İntroduction. Quelle culture politique en héritage?' (2011) (15) 1 Parlement(s) Revue d'histoire politique s. 6, 15.

Breen M. P., 'Law, Society, and the State in Early Modern France' (2011) (83) 2 The Journal of Modern History s. $346,386$.

Brenner C., iç 'Les Différentes missions du juge de cassation' iç Guillaume Drago, Bénédicte Fauvarque-Cosson ve Marie Goré (edr) L’accès au juge de cassation Colloque du 15 Juin 2015 (Collectif 2015) s. 29, 45. 
Burgelin J.F., 'L'Organisation interne de la Cour de cassation favorise-t-elle lélaboration de sa jurisprudence' iç Nicolas Molfessis (edr) La Cour de cassation et L'Élaboration du Droit (Economica 2004), s. 21, 31.

Cadiet, L., 'Ouverture', iç Réformer La Cour de Cassation, Le Projet de Réforme en Débat, Actes du colloque du 11 avril 2019 (IRJS Editions 2019), s. 19, 25.

Carbasse, J.M., 'Le juge entre la loi et la justice: approches médiévales, La conscience du juge dans la doctrine judiciaire à l'aube des Temps modernes' iç La conscience du juge dans la tradition juridique européenne (PUF 1999), s. 67, 94.

Chaline O., 'Cassations et évocations dans les remontrances des parlements Au XVIII e.' (2010) (29) 3 Histoire, économie \& société s. $57,68$.

Chaline O., 'Ouverture' (2010) (29) 3 Histoire, économie \& société, s. 3, 4.

Chénon E., Histoire générale du droit français public et privé des Origines à 1815, 1er Tome (Receuil Sirey 1926).

Claerr R., 'Les Présidiaux créations, suppressions, archives et bibliographie' (2011) Annuaire-Bulletin de la Société de L’histoire de France, 98.

Coste L. 'Des corps intermédiaires sous l'ancien régime: revendication ou réalité?' (2016) (35) 1 Histoire, Économie Et Société, s. 14, 23.

Crépon T., Pourvoi en cassation en matière civile, 1er Tome, (Librairie du Receuil Général des Lois et des Arrêts 1892).

Daireaux L., 'Le parlement de Normandie et l'édit de Nantes: une bataille de dix ans (1599-1610)' (2015) (122) 3 Annales de Bretagne et des Pays de l'Ouest s. 77, 87.

Duquesne Q., 'Du juge seigneurial au juge de paix. Les détenteurs des fonctions judiciaires de proximité de la fin de l'Ancien Régime au Consulat: le cas de l'Isère' (2010) (29)2 Histoire, économie \& société s. 45, 64.

Félix J., 'Comprendre l'opposition parlementaire,Le Parlement de Paris face aux réformes de Silhouette (1759)', (2011) ( 15)1 Parlement(s), Revue d'histoire politique, s. 31, 43.

Ferrand F., Cassation française et révision allemande (PUF 1993).

Forcadet P.A., 'Les premiers juges de la Cour du roi au XIII e siècle' (1922) (94)2 Revue historique de droit français et étranger s. 189, 273.

Godin X., 'La procédure de cassation au XVIIIe siècle' (2010) (3) Histoire, économie \& société s. 19, 36.

Gravier H., 'Essai sur les Pprévots royaux du XI e au XIV e siècle' (1903) (27) 5 Nouvelle revue historique de droit français et étranger s. 648, 672.

Guenée B., 'Le Conseil du roi au Moyen Age' (1999) (52) 3 La Revue administrative s. 5, 9.

Halpérin J.L., 'Le droit privé de la Révolution: héritage législatif et héritage idéologique'(2002) (2) Annales historiques de la Révolution s. 135, 156.

Hamscher, Albert N., The Conseil Privé and the Parlements in the Age of Louis XIV: A Study in French Absolutism (Transactions of the American Philosophical Society 1987).

Hufteau Y.L, Le Référé législatif et les pouvoirs du juge dans le silence de la loi (PUF 1965).

Lanzara D., Le pouvoir normatif de la Cour de cassation à l'heure actuelle (LGJD 2017).

Lemaître A. J., 'Le pouvoir réglementaire Les arrêts sur remontrances du procureur général du roi au parlement de Bretagne' (2015) (122) 3 Annales de Bretagne et des Pays de l’Ouest s. 151, 172.

Marion M. 'A Propos de la géographie judiciaire de la France sous l'ancien régime. La Question du ressort des présidiaux' (1905) (89) 1 Revue Historique s. 80, 88.

Martinage-Baranger R. 'Les idées sur la Cassation au XVIII e.' (1969) (47) Revue Historique De Droit Français Et Étranger s. 244, 290. 
Mousnier R., 'Les Règlements du Conseil du Roi Sous Louis XIII' (1946) (82) 2 Annuaire-Bulletin De La Société De L'histoire De France s. 93, 211 (Réglements).

Mousnier R., Le Conseil du Roi de Louis XII à la Révolution (PUF1970) (Conseil).

Mousnier R., 'Le Conseil du Roi de la mort de Henri IV au gouvernement personnel de Louis XIV' (1947) (1) Etudes D’histoire Moderne Et Contemporaine s. 29, 67 (Gouvernement).

Öztek S., 'Temyiz Kanun Yolunun Tarihçesine İlişkin Bazı Tespitler' (2015) (21) 2 Prof. Dr. Mehmet Âkif Aydın’a Armağan MÜHF-HAD s. 119, 127.

Pagès G., 'Le Conseil du Roi sous Louis XIII' (1937) (12) 29 Revue d'histoire moderne s. 293, 324.

Petit J.G., 'La Justice en France, 1789-1939. Une étatisation modèle?' (2002) (1)6 Crime, Histoire \& Sociétés s. $85,103$.

Piant H., Une Justice Ordinaire, Justice Civile et Criminelle Dans La Prévoté Royale de Vaucouleurs Sous L’Ancien Régime (Pesses universitaires de Rennes 2006).

Picca G. ve Cobert L., La Cour de Cassation (PUF 1986).

Pichard-Rivalan M., 'Un parlement débutant ? Les hésitations de l’arrêt civil au parlement de Bretagne (15541570)' (2015) (122) 3 Annales de Bretagne et des Pays de l'Ouest s. 13, 33.

Renoux-Zagamé, M.F., 'Répondre de l'obéissance. La conscience du juge dans la doctrine judiciaire à l'aube des Temps modernes' iç La conscience du juge dans la tradition juridique européenne (PUF 1999), s. 155, 194. Rouland N., Introduction historique au droit (PUF1998).

Royer, J.P. ve Derasse N., Alinne J.P., Durand B., Jean J.P., Histoire de la justice en France, (5e édition, PUF 1995). Saint-Bonnet F. ve Sassier Y., Histoire des İnstitutions Avant1789 (6e édition, LGDJ 2019).

Saint-Bonnet, François, 'Le constitutionnalisme des parlementaires et la justice politique. Les équivoques des lits de justice du XVIIIe siecle”, Quelle culture politique en héritage?' (2011) (15)1 Parlement(s), Revue d'histoire politique 16,30 .

Saupin G., La France à lépoque moderne, (4e édition ,U Histoire 2020).

Scheyven C., Traité pratique des pourvois en cassation (Bruylant-Christophe \& Compagnie 1866).

Storez-Brancourt İ. 'C'est légal parce que je le veux: loi et constitution dans le face à face du roi et du Parlement à la fin de l’Ancien Régime, Le Parlement de Paris face aux réformes de Silhouette (1759)' (2011) (15) 1 Parlement(s), Revue d'histoire politique s. 59, 74.

Swann J., 'Repenser les parlements au xviiie siècle:du concept de l'opposition parlementaire à celui de culture juridique des conflits politiques' iç Alain J Lemaître (edr) Le monde parlementaire au XVIIIe siècle : L'invention d'un discours politique (Presses Universitaires de Rennes 2010) s. 17, 37.

Teomete-Yalabık F., 'Fransız Hukukunda Temyizin Tarihi Gelişimi ve Temyiz Sebepleri’ (İstanbul Üniversitesi Sosyal Bilimler Enstitüsü 2010).

Thireau J.L., 'Le Conseil du roi au XVI e siècle' (1999) (52) 3 La Revue administrative s. 10, 19.

Van Caenegem R.C., History of European Civil Procedure, Civil Procedure, Chapter 2, (Volume XVI New York 1973).

Verpeaux N., 'Maires, Prévôts, Doyens, Les İntermédiaires Entre Seigneurs et Exploitants' (2011) (36) 2 Histoire \& Sociétés Rurales s. 7, 40.

Weber J.F., 'L'Accès au Juge de Cassation et Le Traitement des Pourvois par La Cour de Cassation Française', iç Guillaume Drago, Bénédicte Fauvarque-Cosson ve Marie Goré (edr) Laccès au juge de cassation Colloque du 15 Juin 2015 (Collectif 2015), s. 59, 81.

Yıldırım K., Hukuk Devletinin Gereği: İstinaf (Nesil Matbaacılık 2000). 